\title{
Article \\ Effect of Bacterial Manure on the Properties of Complex Soil and Growth of Ryegrass
}

\author{
Ningning Zhang ${ }^{1,2} \mathbb{D}$, Jiakun Yan ${ }^{2, *} \mathbb{C}$ and Puling Liu ${ }^{3}$ \\ 1 Key Laboratory of Degraded and Unused Land Consolidation Engineering, Ministry of Land and Resources \\ of China, Xi'an 710075, China; Zhangningning1986@163.com \\ 2 College of Life Science, Yulin University, Yulin 719000, China \\ 3 State Key Laboratory of Soil Erosion and Dryland Farming on the Loess Plateau, Institute of Soil and Water \\ Conservation, Chinese Academy of Sciences and Ministry of Water Resources, Yangling 712100, China; \\ pliu@ms.iswc.ac.cn \\ * Correspondence: himingse@163.com or yanjiakun@yulinu.edu.cn
}

Citation: Zhang, N.; Yan, J.; Liu, P. Effect of Bacterial Manure on the Properties of Complex Soil and Growth of Ryegrass. Agronomy 2021, 11, 568. https://doi.org/10.3390/ agronomy 11030568

Academic Editors: Elisa Gamalero, Simone Cantamessa, Patrizia Cesaro and Giorgia Novello

Received: 23 February 2021

Accepted: 15 March 2021

Published: 18 March 2021

Publisher's Note: MDPI stays neutral with regard to jurisdictional claims in published maps and institutional affiliations.

Copyright: ( $\odot 2021$ by the authors Licensee MDPI, Basel, Switzerland. This article is an open access article distributed under the terms and conditions of the Creative Commons Attribution (CC BY) license (https:// creativecommons.org/licenses/by/ $4.0 /)$.

\begin{abstract}
To cope with the growing population, there is a growing demand for more land to be rendered cultivable. A complex soil created by applying soft rocks into sandy soil can be cultivated. However, the strong water-retaining ability and extreme poverty in nutrients of this complex soil has a negative effect on plant growth. To solve this problem, a complex of microbes and bacterial manure (BM) was added to the complex soil. The soil column culture test was used to detect the influence of BM application on soil bulk-density and infiltration parameters, and a pot experiment was conducted to evaluate its effect on the physical and chemical properties of soil, and ryegrass growth. The addition of $0.15 \%$ of BM to the complex soil decreased soil bulk-density, and increased the wetting front migration distance and soil hydraulic conductivity. The BM application also increased soil enzyme activities, which increased the available nitrogen and phosphorus content. As a result, BM increased the ryegrass root and shoot biomass. Overall, this study indicates that BM could be used as an eco-friendly sandy soil conditioner for improving the quality of complex soils, thereby, sustaining agricultural production in arid and semi-arid regions.
\end{abstract}

Keywords: biomass; complex soils; microbial fertilizer; soil infiltration parameters; soil organic matter; soil enzyme activities

\section{Introduction}

A growing world population and global climate change have increased the demand for construction activities, which has induced a reduction in farmland and grain yield $[1,2]$. To address these problems, more and more virgin land has been developed into cultivatable land; that is, sandy land, desert, mining wasteland, and lands located in arid and semiarid regions must be deployed for cultivation [3,4]. Sandy land in arid regions that have low retention of water and fertilizer could be supplied with more water and fertilizers to enable plant growth [5]. In China, desertification of land has progressed rapidly due to high-intensity utilization of land in the past three decades, and the area of land affected by desertification and sandification is $7.1 \times 105 \mathrm{~km}^{2}$ [6]. Although the inappropriate development and utilization of sandy soils are likely to lead to further sandification and desertification, they are still widely used for agricultural production owing to the increasing food demand [7]. Therefore, improving properties of sandy soil, prevention of sandification, and increasing plant productivity are important for sustainable agricultural production. In recent years, soft rocks have been widely used to improve the sandy land in Northwest China [8,9]. Adding soft rocks to sandy soils has been found to improve the hydraulic parameters of soil, and crop yield. The improved hydraulic parameters of the soil increased soil water-holding capacity, and this in turn reduced fertilizer leaching rate [3,7]. However, the lack of nutrients and soil microbiota in these complex soils 
requires urgent improvement. Recently, the application of additional fertilizers such as biochar, microbial fertilizers, and plant growth-promoting rhizobacteria has been widely used in improving soil nutrition $[3,10,11]$. Currently, we know little about the effect of microbiological microbial fertilizer application on complex soils.

Soil microbes are widely used for soil improvement. Microbes improve expansive soils by decreasing their swelling index and linear shrinkage ratios [12], and changing the soil $\mathrm{pH}$ and soil fertilizer statuses, for example, soil potassium and phosphorus [13]. However, the effect of microbe application on complex sandy and soft rock soils has remained unclear. Research focused on the dynamics of soil microbial biomass in the revegetation of desertified lands has confirmed that soil microbial biomass (parameters such as microbial carbon and nitrogen) in the $0-10 \mathrm{~cm}$ and $10-20 \mathrm{~cm}$ layers greatly increased by 1.58-5.59 times and 2.27-6.07 times, respectively, during the revegetation of shrub and arbor chrono-sequentially from 20 to 30 years on the control land, and the soil fertilizer content increased significantly with the increase in microbial biomass [14]. This showed that microbes are important for soil fertilizer availability in sandy soils. In addition, many studies have confirmed that soil microbes can affect soil properties such as bulk-density and $\mathrm{pH}[15,16]$. The main factor involved in this process is the microbe production of secondary metabolites including organic acid, which could decrease the $\mathrm{pH}$, and make the soil incompact and increase the soil porosity to decrease the soil bulk-density. In this study, a complex of microbes and bacterial manure (BM), which contained three kinds of fungi (Aspergillus, Mucor, and Rhizopus) and one type of mycetes (Hansenula polymorpha), was used. The BM can decompose coarse organic matter (crop residues), organic matter, and inorganic fertilizer and make them bioavailable. BM is used in the production of bioorganic fertilizers and bacterial fertilizers. In this study BM was added to complex soils to enhance soil water transport and soil nutrients. Soil properties such as water saturation conductivity, $\mathrm{pH}$, nutrient availability, plant growth, and biomass were investigated in pot experiments using ryegrass seedlings. The results could be referred to in similar areas to previous research, including desertification control, mining repair and wasteland reclamation.

\section{Materials and Methods}

Soft rocks and sandy soil were collected from the Dongsheng District, Ordos city, Inner Mongolia, China. The BM complex was bought from Shaanxi Haomiao Biological Science and Technology Co., LTD. Yulin, Shaanxi, China. The physical properties of sandy soil and soft rocks are shown in Table 1.

Table 1. Primary physical properties of sand soil and soft rock in the study site.

\begin{tabular}{cccccccccc}
\hline Material & Texture & Sand (\%) & Silt (\%) & Clay (\%) & $\begin{array}{c}\text { BD (Mg } \\
\left.\mathbf{m}^{-3}\right)\end{array}$ & $\begin{array}{c}\text { TN } \\
(\mathbf{g} / \mathbf{k g})\end{array}$ & TP & $\begin{array}{c}\text { Organic } \\
\text { Matter (\%) }\end{array}$ \\
\hline $\begin{array}{c}\text { Aeolian } \\
\text { sandy soil }\end{array}$ & Sand & 94.6 & 4.3 & 1.1 & 1.57 & 0.08 & 0.24 & 7.4 & 0.153 \\
\begin{tabular}{c} 
Soft rock \\
\hline
\end{tabular} & - & 18.9 & 32.1 & 49 & 1.33 & 0.02 & 0.71 & 8.1 & 0.165 \\
\hline
\end{tabular}

Note: Percentage of clay $(<0.002 \mathrm{~mm})$, silt $(0.002-0.05 \mathrm{~mm})$, and sand $(0.05-2 \mathrm{~mm})$ particles, measured by the pipette method; BD, bulk-density, measured by the undistributed soil core method; Total N, determined using the Kjeldahl method, soil $\mathrm{pH}$ was measured with a soil/water ratio of 1:2.5 using an ion $\mathrm{pH}$ meter.

\subsection{Effect of BM Application on Complex Soil Properties}

As previous studies have shown, the complex soil (CS) was obtained by mixing sandy soil and soft rocks in a ratio of 3:1 [3,5]. In this experiment, BM was added to CS in the following mass (\%) of CS: $0,0.05,0.10,0.15$, and 0.20 , with the $0 \%$ addition being the control. Each treatment was replicated ten times. The one-dimensional vertical infiltration method was used to conduct the water infiltration test [17]. A graduated plexiglass column with $0.5 \mathrm{~mm}$ holes evenly distributed at the bottom was used to hold the test soil (Figure 1). The bulk-density of the filled soil in the soil column was the soil bulk-density in its natural state. The bulk-density was controlled during the filling process, and it was filled every $5 \mathrm{~cm}$ for a total of $20 \mathrm{~cm}$. To prevent stratification, brush hairs were used for each layer. The bottom 
of the plexiglass was filled with filter paper and gauze to prevent the loss of soil sample particles. After completion of filling the plexiglass, natural settlement was allowed to occur for one week. After this, six replications were used to detect infiltration parameters and four replications were used to detect soil bulk-density [18].

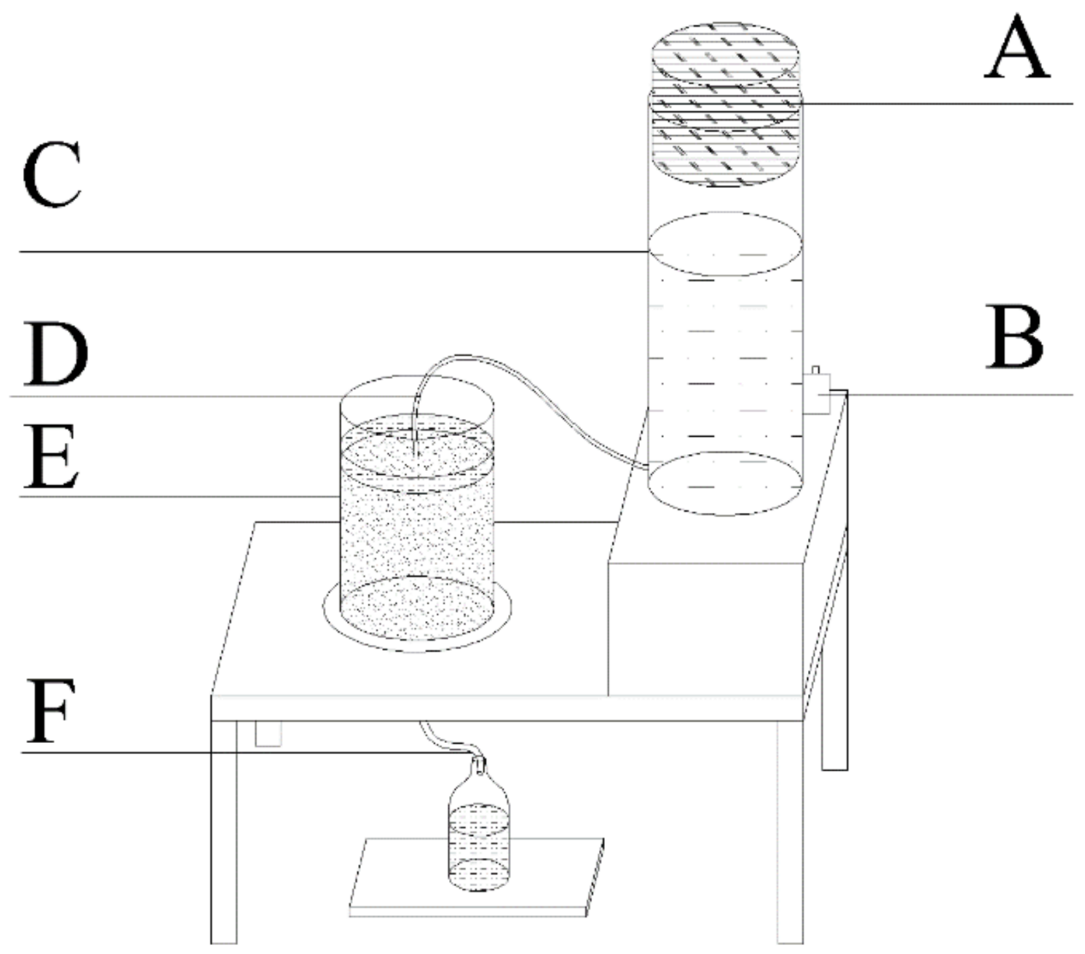

Figure 1. Diagram of the experiment setup. (A), Rubber plug; (B), air inlet; (C), Markov bottle; (D), water inlet; (E), soil column of text and (F), water outlet.

A martensitic bottle with an inner diameter of $5 \mathrm{~cm}$ was used for water supply, and the water supply head was controlled at about $4.5 \mathrm{~cm}$. The $50 \mathrm{~mL}$ volumetric bottle was used to collect the outflow. The height of the water surface dropped in the martensitic bottles and the vertical migration distances of the wetting peaks in the soil column were recorded by photography. The initial infiltration began with the opening of the valve and ended with the wet front. In the leakage stage, the first drop of water from the bottom of the earth column was timed and the discharge was recorded 10 times every $1 \mathrm{~min}$, followed by a discharge of 5 times every $2 \mathrm{~min}$, and the discharge was recorded in the last $5 \mathrm{~min}$ until the change of outflow volume tended to be stable enough to obtain the saturation conductivity. After the infiltration test, the test column was placed down for $8 \mathrm{~h}$ to remove gravity water. The soil samples in the column were collected using a cutting ring for the determination of soil bulk-density. During the infiltration test, the temperature was controlled at $26{ }^{\circ} \mathrm{C}$ to facilitate BM growth and reproduction in the soil column.

The water conductivity was calculated as follows:

$$
\mathrm{K} \_\mathrm{s}=\mathrm{VL} / \mathrm{TAH}
$$

where $\mathrm{H}$ is the head height $(\mathrm{cm}), \mathrm{V}$ is the discharge of water from the outlet $\left(\mathrm{cm}^{3}\right), \mathrm{T}$ is the water outflow time (s), L is the length of the soil column (cm), and A is the cross-sectional area of the soil sample $\left(\mathrm{cm}^{2}\right)$.

\subsection{Effect of BM Application on the Growth of Ryegrass}

A pot experiment using ryegrass (Lolium perenne L.) was conducted. In the first experiment, $0.15 \%$ of $\mathrm{BM}$ was added to CS. The experiment was designed for a normal yield pattern $\left(90 \mathrm{~kg} \mathrm{~N} \mathrm{hm}^{-2}\right.$ and $\left.45 \mathrm{~kg} \mathrm{P} \mathrm{hm}^{-2}\right)$, two soil water contents of well-watered 
control (WW), field water capacity (FWC) (WW, $70 \pm 5 \%$ FWC) and water deficit (WD, $35 \pm 5 \%$ FWC). The pot's dimensions were $20 \mathrm{~cm} \times 35 \mathrm{~cm}$, and it contained $9 \mathrm{~kg}$ of CS. The BM and fertilizers were mixed with the CS before barreling. First, the seeds were disinfected with $3 \% \mathrm{NaClO}$ and washed with double-distilled water. Then, six seeds were planted per pot, and the pots were placed in a rainproof shed. When the seedlings grew to the three-leaf stage, thinning to three seedlings of the same size per pot was conducted, and the water deficit was added using the weighing method.

The measurements were conducted after forty days of treatment. Before biomass measurement, plant height and leaf (new fully unfolded leaf) size were measured with a ruler (Deli Group, Ningbo, China). Then, the ratio of the leaf length and width was calculated. Leaf net photosynthesis rate and transpiration rate were measured between 10:00 and 11:00 a.m. at the center of the newest, fully expanded leaf under ambient conditions using an Li-6400 portable photosynthesis system (Li-COR Biosciences, Lincoln, NE, USA) [3] and the same leaf was used to detect other leaf indexes. The biomass and root/shoot ratio were obtained from a previous study [19]. Leaf nitrogen was detected using Sun's method [3]. The efficiency of water use was calculated as biomass/water usage amount in the whole experiment.

Rhizosphere soil samples were collected to measure the soil nutrients. The soil and leaf nutrient measurements were conducted according to the methods described by Bao [18]. The soil organic matter was measured using the potassium dichromate oxidation heating method. The soil $\mathrm{pH}$ was detected using a benchtop $\mathrm{pH}$ meter (Seven Excellence $\mathrm{pH}$ Meter, Mettler-Toledo, Greifensee, Switzerland). Three enzymes (phosphatase (PA; EC 3.1.3.2), urease (UA; EC 3.5.1.5), and $\beta$-glucosidase ( $\beta$-GA; EC 3.2.1.21)) were tested to analyze the enzyme activity. The soil UA was assayed by estimating the ammonium $\left(\mathrm{NH}^{4+}\right)$ produced by using colorimetric methods after adding urea to soil subsamples [20]. Soil PA and $\beta$-GA were detected using the method proposed by Li [21]. According to the experimental design, the detections were carried out for four replications, and each replication held two technological replications.

\subsection{Data Analysis}

The effects of the treatments on the measured variables were evaluated using one-way analysis of variance (ANOVA). When the F-values were significant, the least significant difference (LSD) test was used to compare mean values through the SPSS software (SPSS Inc., Chicago, IL, USA). The figures were created using SigmaPlot 12.5 (Systat Software Inc., San Jose, CA, USA).

\section{Results}

\subsection{Effect of BM on Bulk-Density}

Soil bulk-density did not change significantly with the addition of soft rock to sandy soil $(p<0.05$, Figure 2). The bulk-density of CS decreased with the addition of BM. The CS with $0.15 \%$ BM showed a significant decrease in bulk-density at $1.53 \mathrm{~g} / \mathrm{cm}^{3}$, compared to the CS without BM at $1.61 \mathrm{~g} / \mathrm{cm}^{3}$. This shows that the addition of microbes can decrease the bulk-density of soil. 


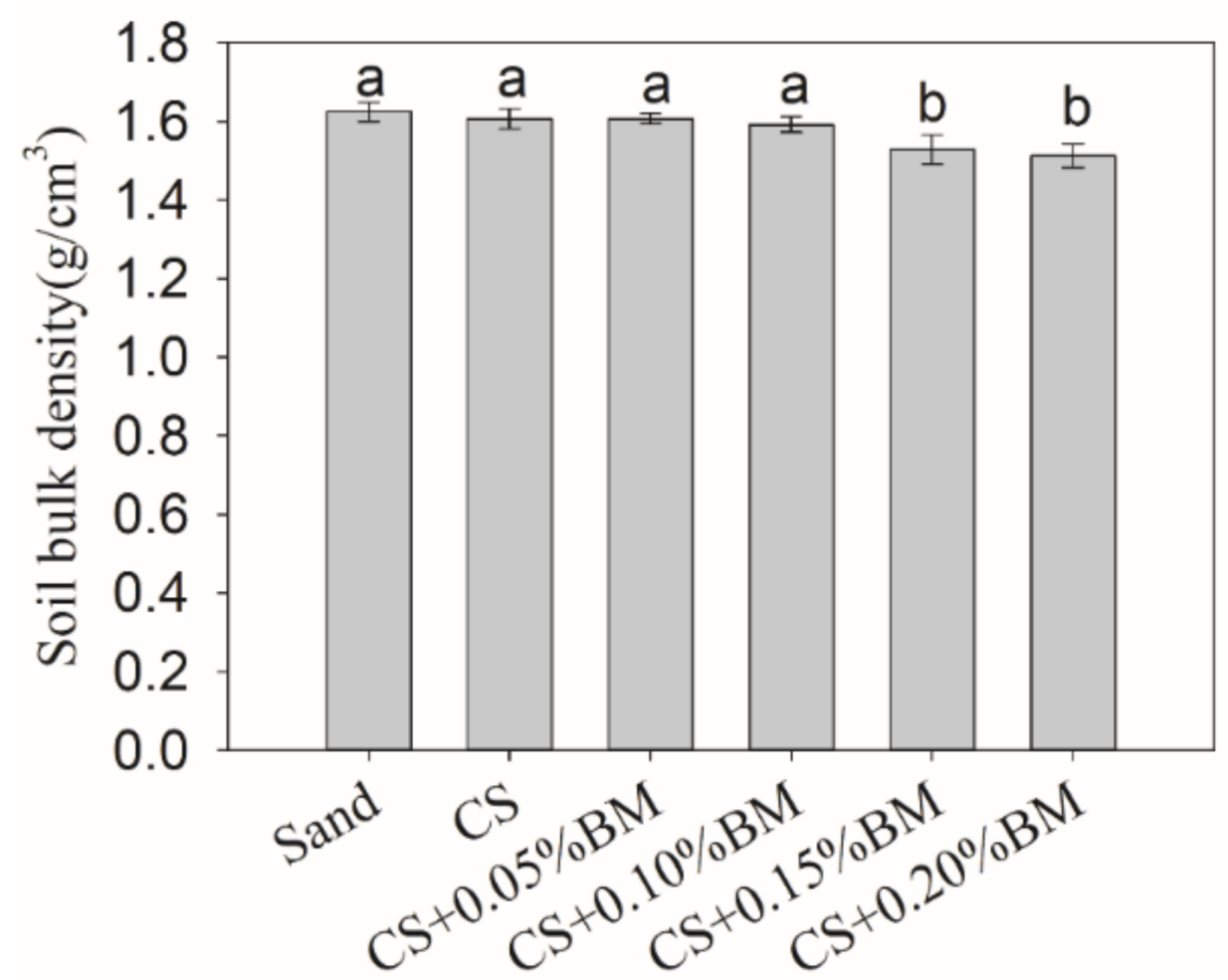

Figure 2. Effect of bacterial manure (BM) application on soil bulk-density. CS: complex soil from sandy soil and soft rocks. The BM was added in an $\mathrm{m} / \mathrm{m}$ ratio. The different letters indicate significant difference $(p<0.05)$. The percentage represents the mass ratio of $\mathrm{BM}$ added.

\subsection{Effect of BM on Infiltration Parameters}

The wetting front exhibited the same trend with time in terms of migration distance and time of infiltration. The BM application of $0.15 \%$ showed the largest migration distance of the wetting front (Figure 3). The CS held the slowest migration distance among the treatments, followed by a BM application of $0.05 \%, 0.1 \%$, and $0.2 \%$. The minimum migration time of the wetting front was found in the $0.15 \%$ application of BM application, followed by $0.20 \%, 0.10 \%, 0.05 \%$, and CS (0\%) treatments (Figure S1). The CS treatment held the largest index for accumulation infiltration at the initial phase, followed by $0.15 \%, 0.1 \%, 0.05 \%$, and $0.20 \%$ of BM application (Figure S2). However, at the stabilization stage, the accumulation infiltration at one hour was $271.5 \mathrm{~mL}$ in the CS treatment, and $280.9 \mathrm{~mL}, 307.7 \mathrm{~mL}, 422.7$ $\mathrm{mL}$, and $267 \mathrm{~mL}$ for $0.05 \%, 0.10 \%, 0.15 \%$, and $0.20 \%$ of BM addition, respectively (Figure S3). This shows that at the initial phase, CS allows a large amount of water to pass through, while at the stabilization stage, water passage is limited in the CS treatment. Finally, after $0.15 \%$ of BM addition, water passage is effectively decreased. 


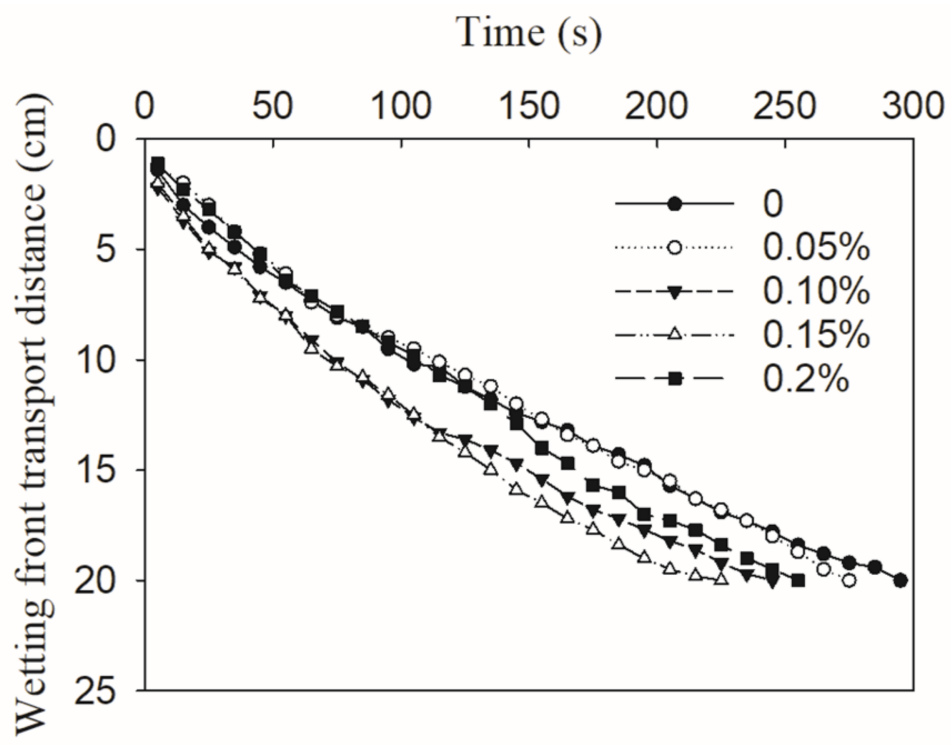

Figure 3. Variation characteristics of migration distance of complex soil wetting front under different $\mathrm{BM}$ addition ratios. The percentage represents the mass ratio of $\mathrm{BM}$ added.

In terms of soil hydraulic conductivity, the soil with $0.15 \% \mathrm{BM}$ addition exhibited the highest value among the treatments $(p<0.05$, Figure 4$)$. Compared with the control CS, BM additions of $0.05 \%, 0.15 \%$, and $0.10 \%$ increased the soil hydraulic conductivity significantly $(p<0.05)$. With the BM application of $0.20 \%$, the increase in soil hydraulic conductivity was not significant $(p>0.05)$.

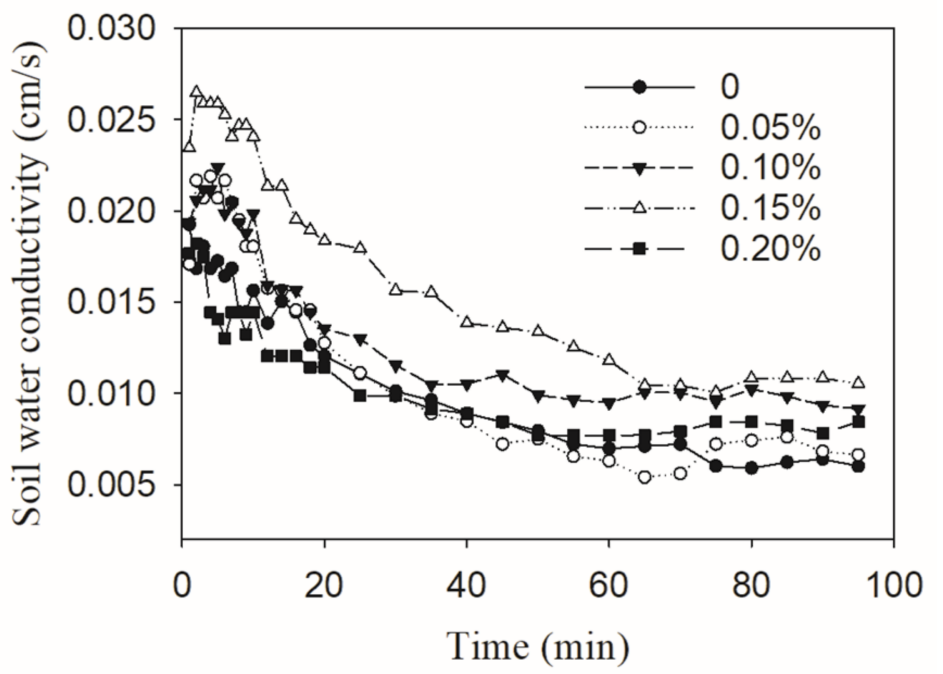

Figure 4. Variation characteristics of water conductivity of complex soil under different BM addition ratios. The percentage represents the mass ratio of BM added.

Consequently, adding $0.15 \%$ BM could decrease the soil bulk-density and increase soil water conductivity.

\subsection{Effect of BM Application on Ryegrass and Soil Properties}

After 55 days of planting, the water deficit decreased the biomass significantly (Figure 5A). However, the application of BM increased the biomass under water deficit conditions. The mean of the biomass with BM application was higher than that without BM, while there was no significant difference. The root dry weight showed results similar to that of the biomass, demonstrating increased root dry weight with BM application $(p<0.05$, Figure 5B). The root/shoot ratio with the BM application treatment had a higher index 
when compared to the no-BM treatment under water deficit conditions (Figure 5C). Water deficit conditions increased the water-use efficiency significantly $(p<0.05$, Figure $5 \mathrm{D})$, and $\mathrm{BM}$ application significantly increased the water-use efficiency under the same treatment $(p<0.05)$. The plant height ranged from $24 \mathrm{~cm}$ to $27 \mathrm{~cm}$ (Figure S4). Water deficit conditions decreased the plant height significantly in the no-BM treatment soil. The application of BM alleviated growth inhibition caused by drought to maintain a relatively high plant height. Leaf length exhibited similar results to plant height (Figure S4). In terms of leaf width, there was no significant difference among the treatments (Figure S4). The leaf length/width ratios significantly increased with $\mathrm{BM}$ application under water deficit conditions $(p<0.05$, Figure S4).
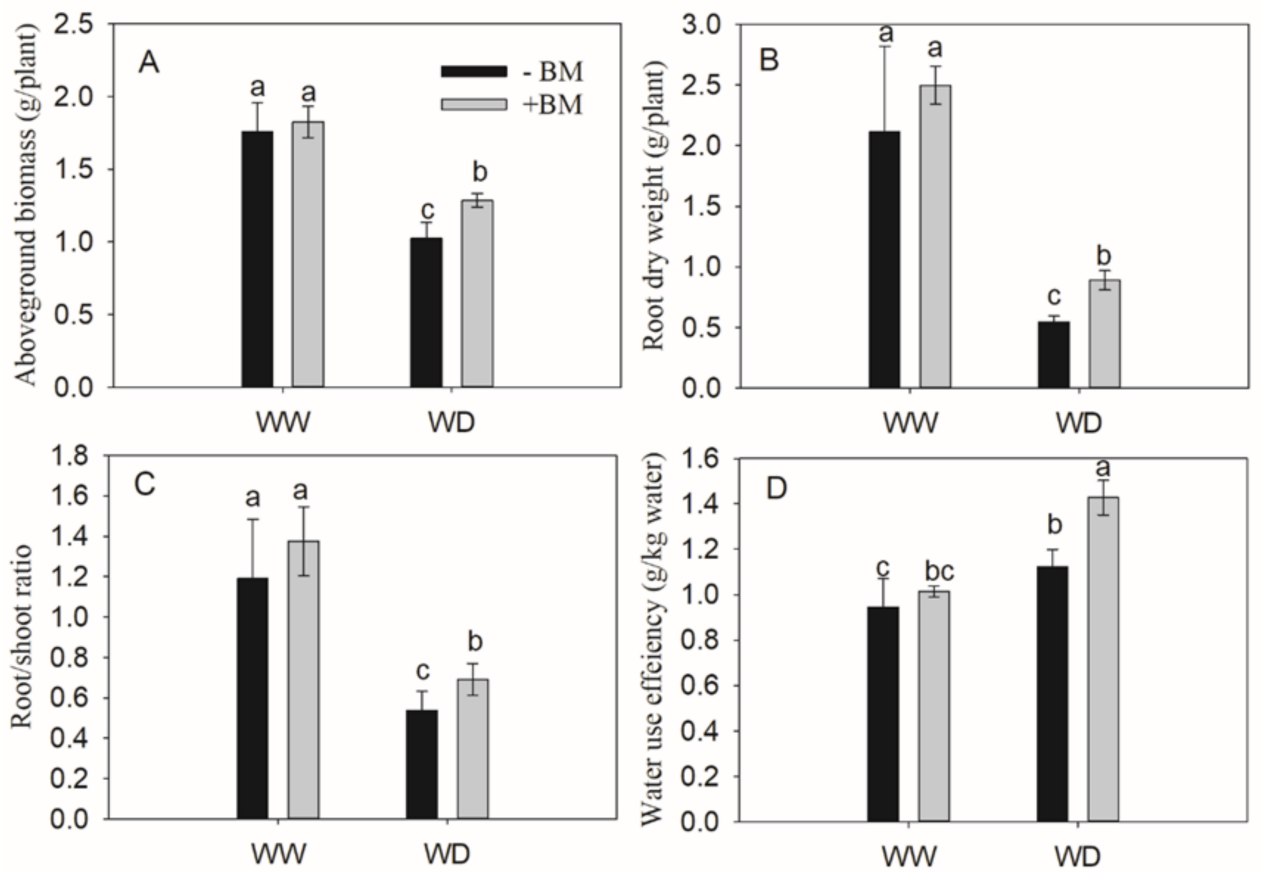

Figure 5. Effect of BM application on plant biomass (A), root biomass (B), root/shoot ratio (C) and water-use efficiency (D) of ryegrass under two water status. The well-watered control (WW) and water-deficit (WD) show the different soil water contents. The different letters indicate significant difference $(p<0.05)$.

BM application increased photosynthetic rate significantly under water deficit conditions, while there was no significant difference between BM application and no-BM application under well-watered conditions (Figure 6). The same trend was found in transpiration rate. Under well-watered conditions, there was no significant difference between $\mathrm{BM}$ application and no-BM application on leaf nitrogen and phosphorus content, while under water deficit conditions BM application increased the leaf nitrogen and phosphorus content significantly $(p<0.05$, Figure 6$)$. 

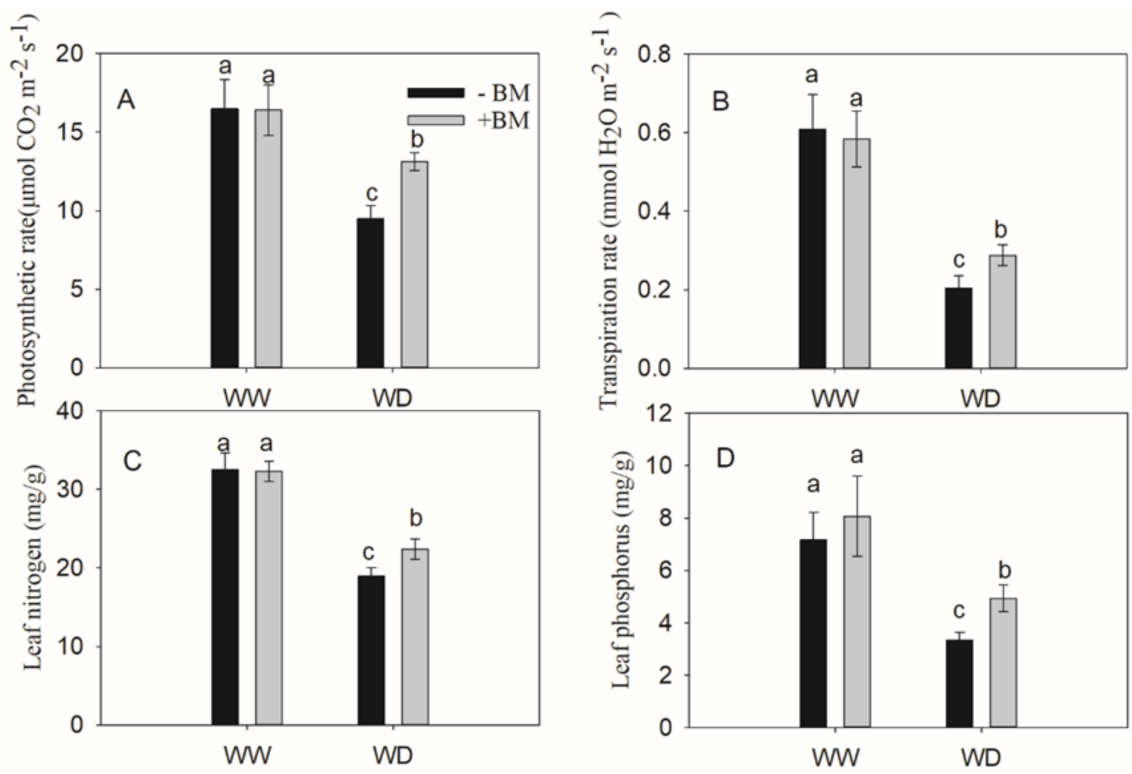

Figure 6. Effect of BM application on leaf photosynthetic rate (A), transpiration rate (B), nitrogen (C) and phosphorus (D) of ryegrass under two water status. WW and WD showed the different soil water contents. The different letters indicate significant difference $(p<0.05)$.

$\mathrm{BM}$ application decreased soil $\mathrm{pH}$, but no significant difference between $\mathrm{BM}$ application and no-BM application under both soil water conditions was observed $(p>0.05$, Figure 7A). Water deficit conditions and BM application increased soil organic matter, while under different water conditions, no significant difference between BM treatments was observed (Figure 7B). Under well-watered conditions, BM application decreased the total nitrogen and phosphorus in the soil (Figure 8), while under water deficit conditions, there was no significant difference between BM application and no-BM application. Under both soil water contents, BM application increased the available nitrogen and phosphorus in the soil significantly $(p<0.05$, Figure 8$)$. Compared to the corresponding CS, the addition of BM increased urease, phosphatase, and $\beta$-glucosidase activities under both soil water contents $(p<0.05$, Figure 9$)$.
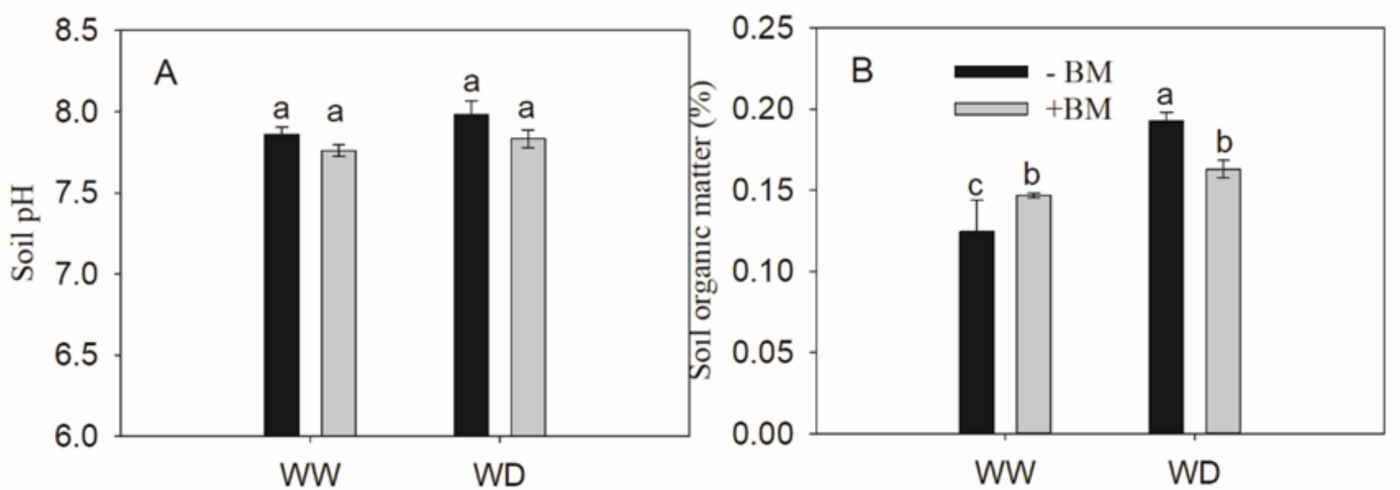

Figure 7. Effect of BM application on soil $\mathrm{pH}(\mathbf{A})$ and organic matter (B) under two water status. WW and WD show the different soil water contents. The different letters indicate significant difference $(p<0.05)$. 

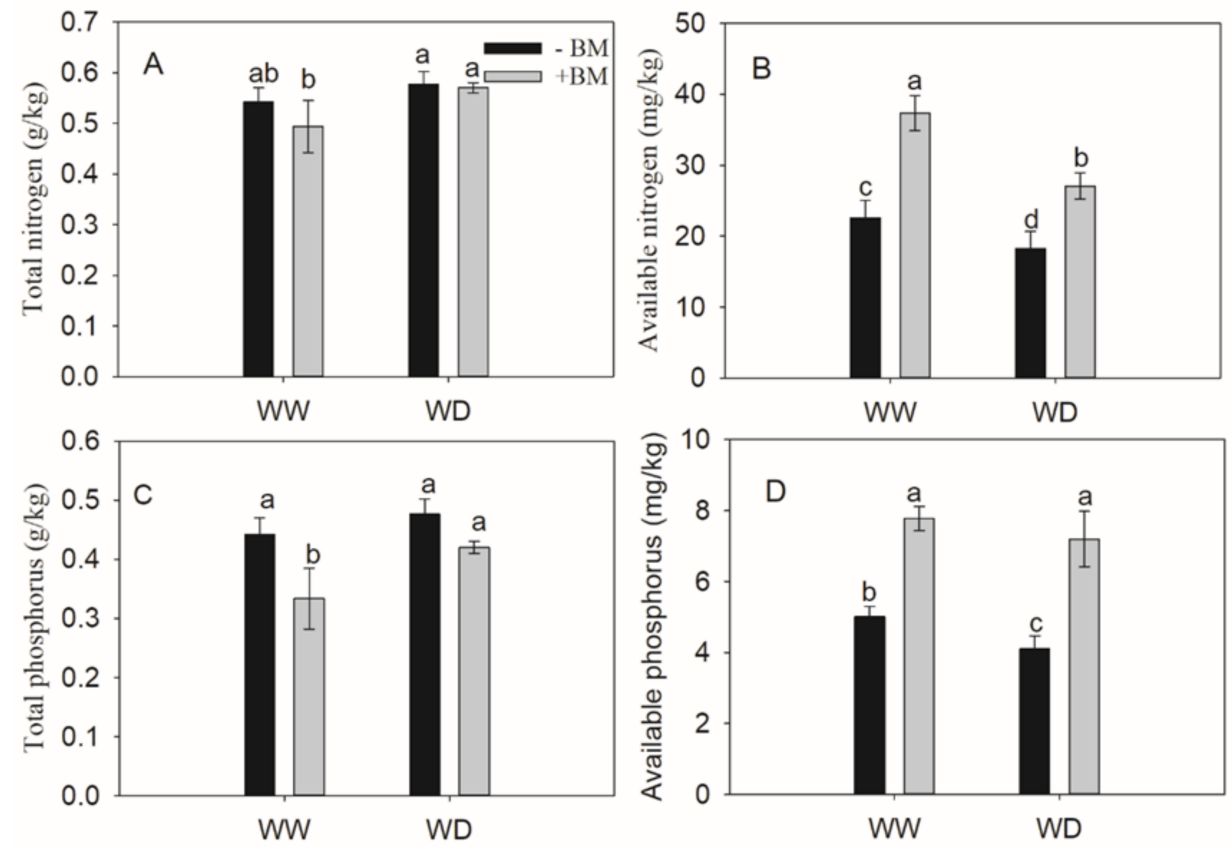

Figure 8. Effect of BM application on total nitrogen (A), total phosphorus (B), available nitrogen (C) and available phosphorus in the soil (D) under two water statuses. WW and WD showed the different soil water contents. The different letters indicate significant difference $(p<0.05)$.
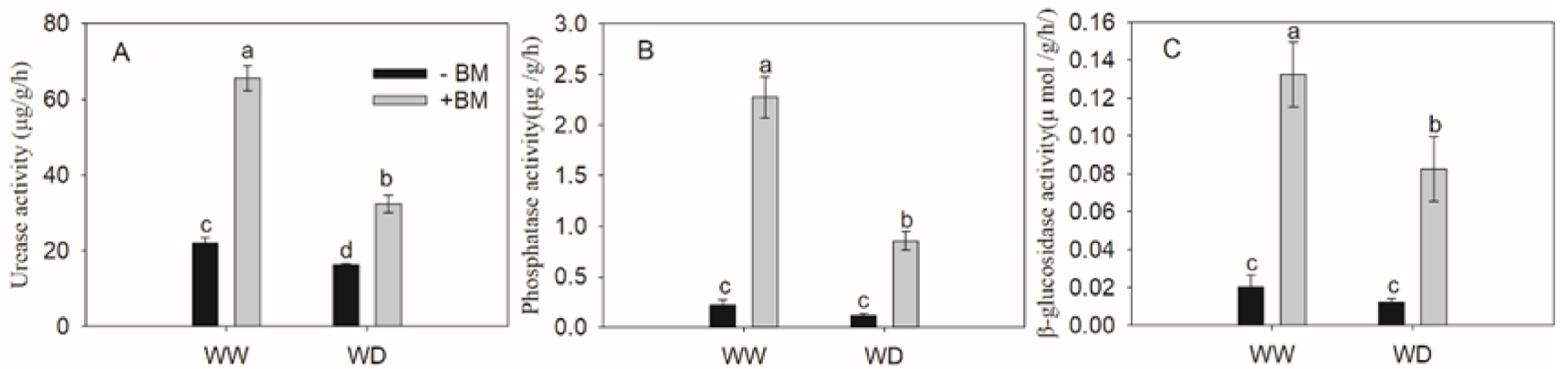

Figure 9. Effect of BM application on soil urease (A) phosphatase (B) and $\beta$-glucosidase activity (C) under two water statuses. WW and WD showed the different soil water contents. The different letters indicate significant difference $(p<0.05)$.

\section{Discussion}

Sandy soils, which are characterized by low nutrient content and poor water and fertilizer retention, occupy a large proportion of the global arable land [22]. Multifarious approaches are used to improve the crop productivity of sandy soils such as fertilization, returning straw to fields, cultivation modes, and microbial fertilizer. Among these approaches, microbes can improve soil properties, and increase soil water and fertilizer retention capacities and crop productivity [23]. In the present study, the traditionally and widely used fungus fertilizer termed BM was used to study its effect on CS properties. The results showed that the application of BM improves the properties of CS and plant growth significantly. This study demonstrates that BM can be used as a novel soil conditioner in CS to obtain the sustainable development of agriculture.

\subsection{Application of BM Improves Physical Properties of Complex Soil}

Soil bulk-density is highly correlated with the physical properties of soil such as texture and structure. These physical properties affect the ability of the crop root to penetrate soil to reach and absorb water and nutrients [5]. In general, a higher soil bulk-density promotes soil water retention during seasons with less-than-average precipitation [23]. 
Many researchers have established that for sustainable tillage, the soil bulk-density in the top soils that support crops should be $1.4-1.5 \mathrm{~g} / \mathrm{cm}^{3}[24,25]$. However, CS has a higher soil bulk-density of $1.62 \mathrm{~g} / \mathrm{cm}^{3}$, and should retain water acutely in this area where rainfall occurs from July to September, with a single maximum rainfall event exceeding $200 \mathrm{~mm}$ [3]. High soil bulk-density could lead to the excess absorption of water that could have negative effects on plant growth [26]. The application of BM in the present study reduced soil bulkdensity at $0.15 \%$ addition. Microbial management in field research confirmed that without tillage, increasing microbial biomass reduces soil bulk-density $\left(1.32 \mathrm{~g} / \mathrm{cm}^{3}\right)$ [27]. In fact, many microbes were found to reduce soil bulk-density [16]. Microbes that breed in soil penetrate and increase soil porosity, thereby reducing soil bulk-density. This explains the reason for the reduction in soil bulk-density with the application of BM.

In the present study, the wetting front caused by the application of BM displayed a larger migration distance and accumulation infiltration. It was found that adding straw to the field increases the porosity of soil, which increases the transport rate of the wetting front and accumulation infiltration [28]. These changes, induced by the application of BM, reduce soil bulk-density. Sandy soils have high hydraulic conductivity [29] and lower waterholding capacity than the finer-textured soils because of their high porosity. Most of the pores in soft rock are small, leading to its high water-holding capacity. Soft rock decreases saturated hydraulic conductivity in the $0-30 \mathrm{~cm}$ soil layer. Sandy soil has predominantly large pores, and therefore the movement of soil water through it is relatively unhindered and fast [5]. However, this behavior was less noticeable in all the treatments with the added soft rock. With an increase in the quantity of soft rock added to sandy soil, the content of silt-sized and clay-sized grains gradually increased, and the sand-sized grains significantly decreased. The strong ability to retain water induced a harmful effect for plant growth; however, BM application increased soil hydraulic conductivity and reduced the negative effect caused by adding soft rock. Research has shown that the consequence of self-organization, induced by microbial diversity for the functioning of soil, is determined using the Lattice-Boltzmann simulation of fluid flow through the observed structures, and it predicts that the resultant micro-structural changes can significantly increase hydraulic conductivity [30]. The present study shows that BM-induced improvement in soil hydraulic conductivity is because of microbial activity increasing pore numbers and sizes.

\subsection{Application of BM Improves Chemical Properties of Complex Soil}

Microbe application in the soil could decompose soil organic matter into acidic materials like $\mathrm{H}_{2} \mathrm{~S}$, which would decrease soil $\mathrm{pH}$ [31]. Here, adding BM decreased the soil $\mathrm{pH}$; however, there was no significant difference in the soil $\mathrm{pH}$ among the treatments. The potential reason could be the short experiment cycle. Soil organic matter and nutrient level are important indicators for evaluating soil quality, and they are also affected by the application of soil conditioners [32]. In this study, BM application decreased organic matter content under water deficit conditions, which would be induced by higher enzyme activities that could accelerate the decomposition of organic matter [33]. Due to the higher enzyme activity, including that of urease and phosphatase, the available nitrogen and phosphorus increased.

\subsection{Application of BM Promotes Plant Growth and Water-Use Efficiency under Water Deficit Conditions}

The photosynthetic rate was an important index in evaluating plant growth [3]. Under water deficit conditions, BM increased the photosynthetic rate significantly, and this result was consistent with previous studies [34]. This could be induced by the higher nitrogen and phosphorus content in the leaf. In general, water deficit would restrain leaf transpiration and reduce root water uptake, so the soil available to nitrogen and phosphorus could not be absorbed by plants with water. Here, adding BM increased the leaf transpiration, which would benefit the available nitrogen and phosphorus absorbed to maintain high leaf nitrogen and phosphorus content. Soil conditioners are best evaluated based on plant growth or yield [35]. In this study, under both water statuses, the application of BM 
increased the ryegrass biomass especially under water deficit conditions, which shows that the BM has great potential as a useful soil conditioner in the CS. In addition, the application of BM enhanced the water-use efficiency markedly. The treatment with BM also increased root size (biomass), which is beneficial to plant growth [36,37]. In essence, BM application increased root growth and aboveground biomass.

\section{Conclusions}

The application of $0.15 \%$ BM decreased bulk-density at $1.53 \mathrm{~g} / \mathrm{cm}^{3}$, compared to CS without $\mathrm{BM}$ at $1.61 \mathrm{~g} / \mathrm{cm}^{3}$, and increased the soil hydraulic conductivity significantly $(p<0.05)$ in complex soils. The application of BM also increased soil enzyme activities, increasing available nitrogen and phosphorus content significantly $(p<0.05)$. Lastly, BM promoted plant growth and water-use efficiency by increasing the photosynthetic rate significantly under water deficit conditions $(p<0.05)$. Therefore, the application of BM effectively enhances plant growth by improving soil chemical and physical properties, and nutrient levels. Overall, this study indicates that BM could be used as an eco-friendly sandy soil conditioner for improving the quality of complex soils made of sandy soil and soft rocks, and foster sustainable agricultural production in arid and semi-arid regions.

Supplementary Materials: The following are available online at https: / /www.mdpi.com/2073-4 395/11/3/568/s1, Figure S1: Migration time of complex soil wetting front under different BM addition ratio. The percentage represents BM added mass ratio, Figure S2: Variation characteristics of cumulative infiltration of complex soil with different $\mathrm{BM}$ addition ratio within $5 \mathrm{~min}$. The percentage represents BM added mass ratio, Figure S3: Variation characteristics of cumulative infiltration of complex soil with different $\mathrm{BM}$ addition ratio under $60 \mathrm{~min}$. The percentage represents $\mathrm{BM}$ added mass ratio. Figure S4: Effect of BM application on plant height, leaf length and width of ryegrass under two water status. A, plant height; B, leaf length; C, Leaf width; D, leaf length/width ratio. WW and WD showed the different soil water content. The different letters indicate significant difference $(p<0.05)$.

Author Contributions: Conceptualization, N.Z. and J.Y.; methodology, N.Z.; software, N.Z.; validation, N.Z., J.Y. and N.Z.; formal analysis, N.Z.; investigation, writing-original draft preparation, N.Z.; writing-review and editing, P.L.; funding acquisition, J.Y. and N.Z. All authors have read and agreed to the published version of the manuscript.

Funding: This research was funded by National Natural Science Foundation of China, grant number 42067016" and "Key Laboratory of Degraded and Unused Land Consolidation Engineering, the Ministry of Land and Resources, grant number SXDJ2018-08" and a Ph.D. Research Start-up Fund from the Yulin University, grant number 17GK19 and 17GK18.

Institutional Review Board Statement: Not applicable.

Informed Consent Statement: Not applicable.

Data Availability Statement: The data could be obtained from the corresponding author.

Acknowledgments: We gratefully acknowledge help from students from Yulin University for their assistance in data collecting.

Conflicts of Interest: The authors declare no conflict of interest.

\section{References}

1. Reyes-Fox, M.; Steltzer, H.; Trlica, M.J.; McMaster, G.S.; Andales, A.A.; LeCain, D.R.; Morgan, J.A. Elevated $\mathrm{CO}_{2}$ further lengthens growing season under warming conditions. Nature 2014, 510, 259-262. [CrossRef]

2. Leisner, C.P. Review: Climate change impacts on food security- focus on perennial cropping systems and nutritional value. Plant Sci. 2020, 293, 110412. [CrossRef]

3. Sun, Y.; Zhang, N.; Yan, J.; Zhang, S. Effects of soft rock and biochar applications on millet (Setaria italica L.) crop performance in sandy soil. Agronomy 2020, 10, 669. [CrossRef]

4. $\quad$ Ellen, R.H.; Yael, M.H.; Max, K.; Eddie, C.; Avner, S.; Dalia, R.D.; Ludmilla, T.; Menahem, B.; Yigal, E. Biochar impact on development and productivity of pepper and tomato grown in fertigated soilless media. Plant Soil 2010, 337, 481-496. 
5. Sun, Z.H.; Han, J.C.; Wang, H.Y. Soft rock for improving crop yield in sandy soil in the Mu Us desert, China. Arid Land Res Manag. 2019, 33, 136-154.

6. Omasa, K.; Nouchi, I.; De Kok, L.J. Plant Responses to Air Pollution and Global Change; Springer: Tokyo, Japan, 2005.

7. Sun, Z.H.; Han, J.C. Effect of soft rock amendment on soil hydraulic parameters and crop performance in Mu Us Sandy Land, China. Field Crop Res. 2018, 222, 85-93. [CrossRef]

8. Han, J.C.; Liu, Y.S.; Luo, L.T. Research on the core yechnology of remixing soil by soft rock and sand in the Maowusu Sand Land Region. China Land Sci. 2012, 26, 87-94.

9. $\quad$ Liang, Z.S.; Wu, Z.R.; Yao, W.Y.; Noori, M.; Yang, C.Q.; Xiao, P.Q.; Leng, Y.B.; Deng, L. Pisha sandstone: Causes, processes and erosion options for its control and prospects. Int. Soil Water Conserv. Res. 2019, 7, 1-8. [CrossRef]

10. Khan, N.; Bano, A.M.D.; Babar, A. Impacts of plant growth promoters and plant growth regulators on rainfed agriculture. PLoS ONE 2020, 15, e0231426. [CrossRef]

11. Grzebisz, W.; Maciejewska, A. Effect of organic fertilizer made from brown coal on the adsorption of heavy metals by sandy soil. Pol. J. Microbial. 1999, 32, 20-21.

12. Du, J.; Zhou, D. Experimental study on improvement of expansive soil with microbe. Water Res. Hydropower Eng. 2012, 43, 103-158.

13. Gao, P.; Wang, J.; Huang, T.Y.; Chen, X.P. Screening of microbe producing organic acid and its application in saline-alkali soil improvement. Chin. Agric. Sci. Bull. 2018, 34, 72-78.

14. Jiao, L.; Tong, X.G.; Awasthi, M.K.; Wu, F.Y.; Ha, S.E.; Ma, J.Y.; Sun, X.H.; Chao, H. Dynamics of soil microbial biomass and enzyme activities along a chronosequence of desertified land revegetation. Ecol. Eng. 2018, 111, 22-30.

15. Yu, Y.; Wang, H.Y.; Ding, G.D.; Ren, L.N.; Sun, J.; Fan, M.R. Quantitative characteristics of soil microbe and its relationship with soil properties in Larix principis-rupprechtii plantations. J. Northeast For. Univ. 2011, 39, 76-80.

16. Milleret, R.; Bayon, R.C.L.; Lamy, F.; Gobat, J.M.; Boivin, P. Impact of roots, mycorrhizas and earthworms on soil physical properties as assessed by shrinkage analysis. J. Hydrol. 2009, 373, 499-507. [CrossRef]

17. Su, L.J.; Wang, J.; Qin, X.Q.; Wang, Q.J. Approximate solution of a one-dimensional soil water infiltration equation based on the brooks-corey model. Geoderma 2017, 297, 28-37. [CrossRef]

18. Bao, S. Soil Agrochemical Analysis; China Agriculture Press: Beijing, China, 2010.

19. Yan, J.K.; Zhang, N.N.; Kang, F.R. Jasmonate improved Cd resistance in maize seedlings by regulating spermidine synthesis. Int. J. Agric. Biol. 2020, 24, 171-178.

20. Xiang, Y.; Xiang, Y.; Jiao, Y.; Wang, L. Effect of sludge amino acid-modified magnetic coal gasification slag on plant growth, metal availability, and soil enzyme activity. J. Soil Water Conserv. 2020, 75, 515-526. [CrossRef]

21. Li, B.; Chen, Y.; Liang, W.; Mu, L.; William, C.; Astrid, R.; Christophe, J. Influence of cerium oxide nanoparticles on the soil enzyme activities in a soil-grass microcosm system. Geoderma 2017, 299, 54-62. [CrossRef]

22. Duan, Z.; Dong, Z.; Gang, W.; Drake, S. Morphological, physical and chemical properties of aeolian sandy soils in northern China. J. Arid Environ. 2007, 68, 66-76.

23. Jonasson, S.; Castro, J.; Michelsen, A. Interactions between plants, litter and microbes in cycling of nitrogen and phosphorus in the arctic. Soil Biol. Biochem. 2006, 38, 526-532. [CrossRef]

24. Dam, R.F.; Mehdi, B.B.; Burgess, M.S.E.; Madramootoo, C.A.; Mehuys, G.R.; Callum, I.R. Soil bulk density and crop yield under eleven consecutive years of corn with different tillage and residue practices in a sandy loam soil in central Canada. Soil Tillage Res. 2005, 84, 41-53. [CrossRef]

25. Heinonen, R. Towards "normal" soil bulk density. Soil Sci. Soc. Am. J. 1977, 41, 1214-1215. [CrossRef]

26. Qin, Z.; Wu, X.J.; Liang, X.; Jiang, H.; Dong, J. Waterlogging and simulated acid rain after anthesis deteriorate starch quality in wheat grain. Plant Growth Regul. 2018, 85, 257-265.

27. Reis, V.M.A.; Silva, C.E.G.; Rodrigues, C.A.M.; Cristina, A.M. Effects of soil management systems on soil microbial activity, bulk density and chemical properties. Pesqui. Agropecu. Bras. 2001, 36, 1539-1545.

28. Hu, B.; Cheng, D.; Zhang, J. Influence of straw row application on moisture migration distribution. J. Irrig. Drain. 2017, 36, 29-32.

29. Hussien, R.A.; Donia, A.M.; Atia, A.A.; El-Sedfy, O.F.; El-Hamid, A.R.A.; Rashad, R.T. Studying some hydro-physical properties of two soils amended with kaolinite-modified cross-linked poly-acrylamides. Catena 2012, 92, 172-178. [CrossRef]

30. Crawford, J.W.; Deacon, L.; Grinev, D.; Harris, A.J.; Ritz, K.; Singh, B.K.; Young, I. Microbial diversity affects self-organization of the soil-microbe system with consequences for function. J. R. Soc. Interface 2012, 9, 1302-1310. [CrossRef] [PubMed]

31. Wang, Y.; Hong, K. Effects of soil factors on microbe distributions in mangrove soil. Chin. J. Trop. Crop 2005, 26, 109-114.

32. Shahrzad, K.; Mahmoud, K.; Hossein, K.A.; Mehran, H.; Majid, A. Effect of incorporation of crops residue into soil on some chemical properties of soil and bioavailability of copper in soil. Int. J. Adv. Biol. Biomed. Res. 2014, 2, $2819-2824$.

33. Wang, T.; Yang, Y.J.; Deng, L.; He, L.Y.; Xu, M.W.; Yang, C.Q.; Liu, Z.S. Effects of different solid microbial agents on soil properties of Pisha sandstone and the growth of alfalfa. Trans. Chin. Soc. Agric. Eng. 2020, 36, 96-102.

34. Xie, X.; Pu, L.; Shen, H.; Wang, X.; Zhu, M.; Ge, Y.; Sun, L. Effects of soil reclamation on the oat cultivation in the newly reclaimed coastal land, eastern China. Ecol. Eng. 2019, 129, 115-122. [CrossRef] 
35. Das, P.; Barua, S.; Sarkar, S.; Karak, N.; Bhattacharyya, P.; Raza, N.; Kim, K.H.; Bhattacharya, S.S. Plant extract-mediated green silver nanoparticles: Efficacy as soil conditioner and plant growth promoter. J. Hazard. Mater. 2018, 346, 62-72. [CrossRef]

36. Rowe, J.H.; Topping, J.F.; Liu, J.; Lindsey, K. Abscisic acid regulates root growth under osmotic stress conditions via an interacting hormonal network with cytokinin, ethylene and auxin. New Phytol. 2016, 211, 225-239. [CrossRef] [PubMed]

37. Pang, J.Y.; Milroy, S.P.; Rebetzke, G.J.; Palta, J.A. The influence of shoot and root size on nitrogen uptake in wheat is affected by nitrate affinity in the roots during early growth. Funct. Plant Biol. 2015, 42, 1179-1189. [CrossRef] [PubMed] 